\title{
Editorial
}

\section{Of DAMPs and Macrophages}

With this first issue of the Journal of Innate Immunity in 2013, we would like to take the opportunity to look back as well as into the future. Starting with one of the most important issues, the 2012 impact factor has increased by more than $60 \%$ and has reached 4.2 . We also see a continuously growing number of submissions, further indicating that the Journal of Innate Immunity has been established within the scientific community. This has resulted in an improvement in the quality of submitted articles and, consequently, an increased rejection rate (>70\%). We would like to take this opportunity to thank the Editorial Board for an excellent and speedy job. So far, the average time from submission to the first decision takes between 2 and 3 weeks; we will try to keep up this standard in the future.

As in past years, we have published a number of Theme Issues covering areas of danger-associated molecular patterns, posttranslational modification of host proteins by bacteria, skin infections, host defense peptides and macrophages. We will continue to have one Editor's Choice article in each issue, to which there will be free access online. So far, the Editor's Choice articles have been well received and they are frequently downloaded from the journal's homepages, e.g. the article by McAdow et al. [1] about a staphylococcal coagulase, the article by Pulido et al. [2] on lipopolysaccharide neutralizing antimicrobial peptides and the review article by Gray and Cyster [3] dealing with lymph node macrophages.

For 2013, we are planning to have 5 theme issues dealing with systems biology, the trafficking of immune cells, autophagy, immunological memory in innate immunity and innate sensing and responses to fungal infestation. If you are interested in contributing to any of these theme issues, please have a look at our homepage (www. karger/jin).

We hope that 2013 will be as successful as previous years for the Journal of Innate Immunity.

Heiko Herwald, Lund Arne Egesten, Lund

\section{References}

1 McAdow M, Missiakas DM, Schneewind O: Staphylococcus aureus secretes coagulase and von Willebrand factor-binding protein to modify the coagulation cascade and establish host infections. J Innate Immun 2012;4:141-148.

-2 Pulido D, Nogues MV, Boix E, Torrent M: Lipopolysaccharide neutralization by antimicrobial peptides: a gambit in the innate host defense strategy. J Innate Immun 2012;4:327-336.

3 Gray EE, Cyster JG: Lymph node macrophages. J Innate Immun 2012; $4: 424-436$

\begin{tabular}{ll}
\hline KARGER & (c) 2012 S. Karger AG, Basel \\
1662-811X/13/0051-0001\$38.00/0 \\
$\begin{array}{l}\text { Fax +41 61306 } 1234 \\
\text { E-Mail karger@karger.ch } \\
\text { www.karger.com }\end{array}$ & $\begin{array}{l}\text { Accessible online at: } \\
\text { www.karger.com/jin }\end{array}$
\end{tabular}

